\title{
Article \\ Monitoring 21st-Century Real-Time Language Change in Spanish Youth Speech
}

\author{
Linde Roels*iD, Fien De Latte and Renata Enghels $(D)$ \\ Department of Linguistics, Faculty of Arts and Philosophy, Ghent University, 9000 Ghent, Belgium; \\ fien.delatte@ugent.be (F.D.L.); renata.enghels@ugent.be (R.E.) \\ * Correspondence: linde.roels@ugent.be
}

Citation: Roels, Linde, Fien De Latte, and Renata Enghels. 2021.

Monitoring 21st-Century Real-Time Language Change in Spanish Youth Speech. Languages 6: 162. https:// doi.org/10.3390/languages6040162

Academic Editors: Juana M. Liceras and Raquel Fernández Fuertes

Received: 3 June 2021

Accepted: 24 September 2021

Published: 8 October 2021

Publisher's Note: MDPI stays neutral with regard to jurisdictional claims in published maps and institutional affiliations.

Copyright: (c) 2021 by the authors. Licensee MDPI, Basel, Switzerland. This article is an open access article distributed under the terms and conditions of the Creative Commons Attribution (CC BY) license (https:// creativecommons.org/licenses/by/ $4.0 /)$.

\begin{abstract}
In recent decades, youth language has become one of the preferred research areas in sociolinguistics, not only because of its non-normative nature but mostly because it is recognized as a catalyst for language change. Since adolescents aspire to create and safeguard an in-group identity, they constantly generate innovative linguistic forms. However, few studies have empirically monitored the speed at which linguistic innovations are introduced into youth language. This study explores the speed and nature of recent language change within Spanish youth language by conducting a corpus analysis in real time. Data of the contemporary CORMA corpus (Corpus Oral de Madrid, compiled between 2016 and 2019) are contrasted with the highly comparable data of the COLAm corpus (Corpus Oral de Lenguaje Adolescente de Madrid, compiled between 2003 and 2007). The study scrutinizes two typical phenomena of youth language, namely the use of intensifiers (e.g., super-, mazo) and vocatives (e.g., tio/tía, chaval/chavala). It is shown that changes occur at a more moderate speed than previously assumed and that the speed of change depends on the linguistic phenomenon under study. Additionally, the data suggest that more neutral forms remain quite stable over time, while the use of more expressive items shrinks or increases faster.
\end{abstract}

Keywords: recent language change; youth language; intensifiers; vocatives; (inter)subjectivity; expressivity; grammaticalization

\section{Introduction}

The first two decades of the 21st century have witnessed a number of important sociocultural changes in Western societies, including Spanish society, which have undoubtedly influenced the languages they use. One of the milestones of the current era is the unstoppable expansion of social media (e.g., Instagram, Twitter, Facebook, TikTok) and streaming services (e.g., Netflix, YouTube) (Jenkins 2009). In 2014, 91.3\% of the young Spanish population was engaged in online social networking (Shoeni et al. 2015). Because of the strong development of social media as a primary means of communication, speakers continually enter into interaction more indirectly rather than engaging in face-to-face conversations. Consequently, conversational rules no longer apply in the same way in these 'mediated' interactions, which may, in turn, have an impact on the strategies applied during a direct conversation. This has resulted in the use of a more informal language in general (Gutzmann 2019). Moreover, given the omnipresence of social media, ideas and particular language use spread more quickly than ever across different networks. Furthermore, with the advance of streaming platforms such as YouTube and Netflix, Spanish speakers are more than ever in contact with foreign languages and cultures, led by the Anglo-Saxon world. As a consequence, although English borrowings entered the Spanish language much earlier, in the current era, there is a considerable increase in their diffusion and use (García Palacios et al. 2016).

Based on these sociocultural (r)evolutions, the 21st century can be considered a time period especially relevant for the observation of current linguistic changes (Aarts et al. 2013, 
p. 1). This paper aims to investigate the speed and nature of recent language change as it occurs in Spanish youth language. It was long believed that children were the main leaders of language change, as they create innovative forms that are later adopted by their parents, generating a 'change from below'. Other scholars point to adults as actors of language change who, through their involvement in contact-induced language change, are said to cause a 'change from above' (Labov 2007, p. 379). However, teenagers have also been identified as linguistic innovators (Zimmermann 2002). It should indeed be highlighted that the abovementioned extralinguistic changes are mainly driven by (Spanish) youth. ${ }^{1}$

Teen language ${ }^{2}$ is known for its versatile nature, as changes occur at an accelerated rate. Since adolescents aspire to create an identity of their own, distinguishing them from other generations, mostly adults, and connecting them with in-group members, they tend to use a broad range of innovative linguistic forms (e.g., Rodríguez González 2002; Tagliamonte 2016). Therefore, they have been defined as 'active neologizers' mostly in the lexical domain (Catalá Torres 2002). Some of these innovative forms end up being integrated into the standard language code, especially when adults imitate the speech of adolescents to rejuvenate themselves (Zimmermann 2002). As a consequence, teenage talk is considered as a catalyst for language change (e.g., Meyerhoff 2006).

Despite the great interest in teen language, there is as yet a lack of longitudinal studies that empirically monitor the linguistic changes produced by young people. Innovation is referred to as a general feature of this variant, but there is no objective account of how fast, why, and where these innovations are produced or not. Moreover, previous studies mostly present a homogeneous model of changing teen language and do not take into account the particular nature of the phenomenon that is being observed. Still, the speed of change is said to vary depending on the linguistic domain. Lexical features are said to change more rapidly whereas syntactic features are considered to be more stable (Trudgill 2020). This paper investigates two lexical phenomena, namely intensifiers and vocatives. ${ }^{3}$

Intensification strategies and the recurrent use of vocative forms-both occurring in example (1) - are recurrently cited in the literature as most typical features of the adolescents' sociolect, both involved in processes of constant renewal.

1. RE2F7: pues me lié con un chaval ¿no? y ahí negro to' guapo tía yo qué sé súper majo y con mucha labia ¿sabes? y y me enamoré tía me enamoré que flipas

('well I hooked up with a guy no? and he was black really handsome girl I don't know super nice and with a lot of lip you know? and and I fell in love with him girl I fell in love like crazy') (CORMA: RE_AM2_F_03) ${ }^{4}$

Intensifiers are said to thrive on innovation, their impact and expressive power being only as good as their novelty (Lorenz 2002; Tagliamonte 2008). The innovations in the intensifying paradigm have been defined as 'fast' and 'dramatic' (Aijmer 2018); even within the lifespan of one generation, processes of obsolescence and renewal can be observed (König 2017). An analogous idea has been formulated about Spanish terms of address, including vocatives, which have been defined as an area in which striking changes can take place (Rodríguez González 2002). ${ }^{5}$

Still, both phenomena are of a quite different nature. The use of intensifiers is mostly linked to the speaker's stance as an expression of his/her emotions. In contrast, vocative forms act upon the interpersonal relationships between speakers. Moreover, both phenomena do not constitute homogeneous classes either, as the use of some members implies a higher degree of expressivity than others. In (1), the use of que flipas is more expressive than the use of $t o(d o)$ or super-; the same applies to vocative forms where the use of tia is more expressive than the use of a proper name. Expressive linguistic units are characterized by semantic independence, i.e., their meaning is separate from the main descriptive content (Potts 2007) but relates to the emotions and the attitude of the speaker (Gutzmann 2019; Hilte et al. 2018). The question arises to what extent highly expressive intensifiers (e.g., fucking in English or puto 'whore' in Spanish) and vocative forms (e.g., coño 'pussy') are faster abandoned by upcoming generations than more neutral ones. Indeed, expressive 
linguistic items are highly compatible with youth language, but when becoming more frequent and productive, they might lose their novelty and as such be abandoned by new generations.

Concretely, we will conduct a real-time analysis of intensifiers and vocatives, through the comparison of their paradigms and uses in two 21st-century corpora documenting Spanish teen talk, namely the COLAm corpus (Corpus Oral de Lenguaje Adolescente de Madrid, compiled between 2003 and 2007) and the CORMA corpus (Corpus Oral de Madrid, compiled between 2016 and 2019). ${ }^{6}$ Following general strategies applied in studies on language change (e.g., Hilpert 2013), particular attention will be paid to (1) changing paradigms, monitoring the creation, diffusion, or obsolescence of particular forms of intensifiers and vocatives in both adolescent generations; and (2) changing productivity, in terms of the token, type, or potential productivity of both phenomena. Increasing productivity of a form at one point in time might lead to an expressivity decrease and, in the end, obsolescence of a particular form in a later phase. The analysis will be oriented by the following questions:

Do both phenomena, intensifiers and vocatives, display similar or different behavior?

Do they engage in comparable cycles of language change, that is with the same kind of forms being added or suppressed from the paradigm, and at a similar speed?

What is the role of the mainly personal vs. interpersonal nature of the phenomena?

And what is the impact of the degree of expressivity of particular items on the speed of change?

The remainder of this article is structured as follows. Section 2 reviews the phenomena of intensification and vocatives and further explains why they are particularly fit for a study on recent youth language change. Section 3 provides more information on the data and the research methodology. Sections 4 and 5 present the results of a detailed corpus analysis and focus on the variation observed within, respectively, the intensifier and vocative paradigm. Section 6 discusses these results and presents some concluding remarks concerning the nature and speed of language change in youth language.

\section{General Background Information on the Observed Phenomena}

Intensification can be defined as a semantic-functional operation realized by different linguistic strategies (Grandi 2017). Intensifiers ${ }^{7}$ can boost an inherent property or descriptive feature of the modified element, both from a quantitative (un montón de gente 'a heap of people') or qualitative (mazo de humilde 'really humble') point of view (Arce Castillo 1999; Napoli and Ravetto 2017). However, intensifiers cannot only be explained in terms of degree modification since they may also highlight an evaluative feature, conveying the speaker's personal attitude, emotion, or opinion with regard to an observed entity, quality, or event (e.g., un examen de mierda 'a shitty exam') (Athanasiadou 2007). With comparative purposes in mind, this case study is mainly concerned with a specific subgroup of morphological (i.e., synthetic) and lexical (i.e., analytic) intensifiers. The morphological intensifying strategies imply suffixes with both an evaluative or superlative value (equipazo 'nice team'; malísimo 'very bad') and intensive prefixes (supermajo 'super cool'), while the lexical devices include both more common degree modifiers (to timido 'very shy') and more expressive intensifiers (el puto viernes 'the fucking Friday'). In all these cases of syntagmatic intensification (Albelda Marco 2007), the intensifiers modify another element. ${ }^{8}$ Importantly, intensifiers can thus vary significantly in terms of their values and expressivity as they have neither the same semantic and pragmatic properties nor the same intensifying force.

Blanco-Suárez (2010) talks about intensifiers in terms of 'fashion victims'. As expressive patterns, they are said to be particularly vulnerable to obsolescence since they risk losing their pragmatic salience if they get overused or diffused (Aijmer 2018; Tagliamonte 2008). Given their continual desire to be original, capture attention, and stay relevant ('fevered invention' in terms of Bolinger (1972)), young speakers easily create and pick up new 'stronger' intensifiers, deserting the older ones (Zimmermann 2002). As intensifiers spread through the community and become more frequent, not only do they lose their expressive power, but they may also lose their function as a "linguistic clue to the identity 
and group membership of the speaker" (Lorenz 2002, p. 143) and accordingly, need to be replaced by new forms.

Vocatives, as the second phenomenon that will be studied, have been defined as (pro)nominal terms of direct address, whose main function consists in attracting the addressee's attention (Moyna 2017; Sonnenhauser and Hanna 2013). ${ }^{9}$ Despite its prototypical attention-getting function, the vocative's multifunctional nature has repeatedly been highlighted, and attention has also been paid to its—not less important—expressive-emphatic and discourse-related uses (Baumgarten 2021; García Dini 1998). As intersubjective and social deictic markers par excellence, they are considered key strategies in the creation and maintenance of interpersonal relationships in interaction (Kluge and Moyna 2019). Consequently, the notions of face (work) and politeness are central issues in the description and study of vocatives (Haverkate 1994).

At a formal level, vocatives can be recognized by their clause-external, non-argumental, and prosodic set-off nature from the sentence (Moyna 2017). This structural isolation is usually marked by pauses in spoken language. Their extra-predicative status explains why vocatives display a high degree of distributional freedom, operating in the left or right periphery of an utterance, in the middle of an utterance, or even independently (Kleinknecht 2013). As regards the linguistic expressions susceptible to assume vocative functions, four main lexical categories can be distinguished in Spanish: (1) proper names (e.g., Martín); (2) titles (e.g., señor 'sir'); (3) nominal terms of address (e.g., guapa 'pretty one'); and (4) second-person pronouns (e.g., tú 'you') (Kleinknecht 2013). Interestingly, in spoken Spanish, the category of nominal terms of address is used most frequently (Brandimonte 2011). Looking at the semantic-pragmatic features of these vocative expressions, we can distinguish the following types: (1) vocatives denoting a certain property of the listener (e.g., age: joven 'youngster'; profession: profe 'teacher'; gender: hombre/mujer 'man/woman'); (2) vocatives describing a relationship between the interlocutors: (a) the so-called familiarizers expressing solidarity and trust (e.g., tronco/a 'dude'; tio/a 'dude'); (b) terms of endearment expressing an intimate, affective relationship (e.g., cariño 'darling'; amor 'love'); (c) kinship terms (e.g., mamá/papá 'mum/dad'); and (d) other types of relationships (e.g., vecino 'neighbor') (Braun 1988; Kleinknecht 2013).

Since nominal terms of address, especially those included in the class of familiarizers or endearments, generally show symptoms of linguistic change and grammaticalization, they have been classified as pragmatic markers (Alba-Juez 2009; Kleinknecht and Souza 2017). These symptoms usually refer to semantic bleaching, as illustrated by hombre 'man', also used in contexts with a female interlocutor (Cuenca and Torres Vilatarsana 2008), and loss of deictic anchoring (Baumgarten 2021). In this respect, it has been stated that, due to their frequent use in daily interactions, these vocatives may lose their direct reference to the hearer, which leads to a reorientation from hearer-oriented uses to discourse-related functions, whereby vocatives come to signal text and turn delimitation or topic shifts, for instance. From a sociolinguistic angle, the vocative's productivity in Spanish teenage talk has been highlighted repeatedly (Rodríguez and Stenström 2011; Stenström 2008). It has been shown that teenagers constantly create and innovate their own in-group terms of address, which mainly serve as distinctive group identity markers, while at the same time reinforcing social bonding within their adolescent peer group (Landone 2009).

From the above descriptions, it can be concluded that the phenomena of intensification and vocatives are an ideal choice for the study of linguistic change.

\section{Materials and Methods}

\subsection{Corpus Data}

When conducting a real-time analysis, one compares the speech of a constant group of speakers over different periods, resulting in a longitudinal study (Cameron 2011). In practice, these are often speakers with comparable backgrounds in comparable settings. Recent real-time linguistic changes can thus only be studied systematically when the researcher has up-to-date data at his or her disposal. The present study builds upon data 
from two oral corpora of Madrilenian Spanish, namely COLAm (Corpus Oral de Lenguaje Adolescente de Madrid; (Jørgensen 2007)) and CORMA (Corpus Oral de Madrid; (Enghels et al. 2020)). The former is representative of youth language at the beginning of the turn of the century, whereas the latter documents present-day youth speech. Importantly, these two corpora accomplish the conditions necessary to conduct a highly comparable real-time variationist study. First, both corpora collect data from Madrilenian Spanish, so the geographical factor remains stable. Due to the prestige of the capital's language, many linguistic innovations emerge in this variant before spreading to more peripheral regions ((Blas Arroyo 2005; Jørgensen and Drange 2012); see also the role of the former Movida Madrileña). Therefore, we expect both corpora to document a highly productive and innovative inventory of intensifying and vocative forms.

Moreover, the COLAm and CORMA corpora present another important advantage as they are elaborated following a similar design. More precisely, the COLAm corpus was recorded between 2003 and 2007 and includes 87 colloquial conversations (463,047 words). The 145 participants are all teenagers between the age of 13 and 19 years (Jørgensen 2013). The CORMA corpus provides 100 colloquial conversations (474,606 words) recorded between 2016 and 2019. The 529 speakers represent four different generations (GEN1: 0-11 y; GEN2: $12-25 y^{10}$; GEN3: 26-55 y; GEN4: 56+y). The corpus of the second generation, the main focus of this paper, contains 37 conversations (154,117 words) between 139 adolescents. Both corpora are characterized by situational and sociolinguistic variation, with a representative number of participants of both genders and different socioeconomic groups. All conversations were almost exclusively between adolescents, and the researchers were not present, nor did they have an active role in the conversations. Although the participants were aware of the fact of being recorded, the obtained data are authentic, which is reflected in the often-intimate topics, the high dynamicity, and cooperative dialogues. The conversations are characterized by the equality between speakers, the familiar discursive scenery, the non-specified conversation topics, the absence of planning, and the interpersonal communicative goals. Hence, they may rightly be defined as prototypical colloquial and spontaneous conversations (Briz Gómez 1998), which are said to favor the appearance of intensifying features and vocatives.

In order to avoid previously observed methodological pitfalls (i.e., regarding different sample sizes, or samples compiled for different purposes; (Pichler 2010)), we compiled a sample of highly comparable conversations in both corpora. ${ }^{11}$ The conversations were selected in such a way that the number of participants as well as their sociological profile (cf. gender and social class) are similar for both samples. Maintaining the stability of these metalinguistic variables is indispensable to reach the proposed objective, namely to measure the impact of time on the linguistic phenomena under scrutiny. The selected set of conversations include both multiparty and one-to-one conversations, which has implications especially for the vocative usage (cf. infra Section 5). ${ }^{12}$ Table 1 further summarizes the number of participants involved in the selected conversations as well as their sociological profile.

Table 1. Sociolinguistic distribution of speakers in COLAm and CORMA.

\begin{tabular}{ccccccc}
\hline & COLAm & \multicolumn{5}{c}{ CORMA } \\
\hline & Low Class & High Class & Total & Low Class & High Class & Total \\
\hline boys & 7 & 9 & 16 & 7 & 7 & 14 \\
\hline girls & 8 & 7 & 15 & 6 & 7 & 13 \\
\hline Total & 15 & 16 & 31 & 13 & 14 & 27 \\
\hline
\end{tabular}

Through a close reading of these conversations, we take stock of the forms under analysis. This bottom-up approach, although time-consuming, has the advantage of revealing new instances since it does not rely on previously listed forms. 
The tokens were annotated manually and a broad range of linguistic variables was included. For the intensifiers, these were: (1) form/type, (2) category (suffixes, prefixes, lexical items), (3) grammatical category of modified base (adjective, adverb, noun, verb), (4) lexeme of modified base, (5) origin of intensifier (nominal, adverbial, adjectival, verbal, other), (6) internal structure of intensifier (e.g., presence of articles, prepositions, conjunctions), and (7) general semantic-pragmatic value (quantitative/qualitative degree modification, positive/negative evaluation, other). For the vocative forms, ${ }^{13}$ these included: (1) form/type, (2) lexical category (proper name, nominal ToA, second-person pronoun), and (3) exclusively for the nominal vocatives, the semantic-pragmatic subcategory (familiarizer, term of endearment, taboo/pejorative term, other). The variables and their corresponding values allowed us to measure the effect of the expressive force on the more or less productive character over time of the intensifiers and vocative expressions included in the paradigm. ${ }^{14}$

\subsection{Parameters of (Recent) Language Change}

That frequency data provide strong evidence for the verification of linguistic hypotheses in general is now widely accepted in the literature. Their validity for the exploration, description, and motivation of language change has also been borne out (Bybee 2003; Hilpert 2013). A frequency change of, and within, a cloud of exemplars can be indicative of processes of language change at a higher level. In this line of ideas, a crucial parameter is productivity, which comes with different quantitative measures, to be calculated for both observed linguistic phenomena (Baayen 2009; Zeldes 2012). First, the measure of the normalized token frequency, i.e., the number of occurrences of a linguistic phenomenon calculated at different time stages, shows whether the phenomenon, intensification or vocatives, has expanded or not over the past two decades. Second, the normalized type frequency or the number of lexical items that can fulfill a certain linguistic function also provides insight into the evolution of that function. A phenomenon is said to become more productive when it accepts more different lexical types (Himmelmann 2004). Since type and token frequency only capture 'realized productivity', we also measured the 'potential productivity' of the linguistic features under analysis by monitoring hapaxes or new items that only occur once in a corpus (Baayen 2009). We then evaluated if and how the frequency of intensifier and vocative forms in youth speech was affected by the time variable (corresponding to the COLAm vs. CORMA corpus). Particular attention was paid to the interaction between time and linguistic variables such as the origins and the degree of expressivity of the form.

The central issue of recent language change will further be operationalized by examining changes in the cloud of exemplars, i.e., the paradigm of lexical types that serves to assume a linguistic function (Bybee 2010). It is indeed important to monitor the provenance of new forms and their process of diffusion. Interestingly, most intensifiers and vocatives do not result from new word-formation strategies but are mostly borrowed or recycled from other grammatical categories. The intensifier mazo, for instance, originated from a (collective) noun and, through a process of grammaticalization, including semantic bleaching, became a frequently used lexical intensifier in the language of young Madrilenian speakers (cf. infra Section 4.3). Similarly, present-day Madrilenian youth speech is permeated by the vocative tio/tia, which is a pragmaticalized form of the original nouns referring to uncles and aunts (cf. infra Section 5.3). Moreover, by taking stock of the forms that are lost, we also looked into factors leading to obsolescence. Does the frequent use or even overuse of a particular form in the first time period lead to its attrition in a later phase? This has been argued repeatedly in the domain of intensifiers (Macaulay 2006; Stenström 2005), but to what extent does this also apply to vocative forms? Being a phenomenon situated at the level of interpersonal communication, do they engage in comparable cycles of language change, that is, with the same kind of forms being added or suppressed from the paradigm and with a similar speed? 


\section{Monitoring Recent Language Change within the Intensifier Paradigm}

\subsection{General Overview}

In the interest of monitoring the recent language change within the paradigm of intensifiers, we first reviewed the normalized token frequency. Table 2 presents the occurrence of morphological and lexical intensifiers (cf. supra Section 2) per 10,000 words.

Table 2. Normalized frequency of intensifiers per corpus.

\begin{tabular}{ccc}
\hline & \# Absolute & \# Normalized \\
\hline COLAm & 191 & 40.9 \\
CORMA & 240 & 85.9 \\
\hline Total & 431 & 57.8 \\
\hline
\end{tabular}

The data reveal a prominent tendency as the use of intensifiers has clearly expanded over the past two decades. Concretely, the data indicate that the use of intensifiers in colloquial youth language has more than doubled, from an average of 40.9 intensifiers to 85.9. Intensification thus seems to be an overall inherent characteristic of the Madrilenian youth sociolect of the 21st century. As can be seen in Table 3, at a more concrete level, it is notable that teenagers today include lexical items in their intensifying acts more frequently than two decades ago (with, respectively, a normalized frequency of 28 and 67.3). The use of suffixes or prefixes with an augmentative or superlative value remains quite stable compared to the lexical strategies.

Table 3. Distribution of general categories of intensifiers per corpus. ${ }^{15}$

\begin{tabular}{ccccccccc}
\hline & COLAm & & & CORMA & & \multicolumn{3}{c}{ Total } \\
\hline & \# & \# norm. & \% & $\#$ & \# norm. & \% & $\#$ & \% \\
\hline prefixes & 21 & 4.5 & 11 & 22 & 7.9 & 9.2 & 43 & 10 \\
suffixes & 39 & 8.3 & 20.4 & 30 & 10.7 & 12.5 & 69 & 16 \\
lexical items & 131 & 28 & 68.6 & 188 & 67.3 & 78.3 & 319 & 74 \\
\hline Total & 191 & 40.8 & 100 & 240 & 85.9 & 100 & 431 & 100 \\
\hline
\end{tabular}

\subsection{Configuration of the Paradigms}

Next, it is interesting to scrutinize changes in the cloud of exemplars, i.e., the paradigm of types that assume the intensifying function in both COLAm and CORMA. Figure 1 presents an overview of the concrete morphological and lexical types ${ }^{16}$ of intensifiers that were extracted from, respectively, the COLAm (left panel) and CORMA (right panel) corpus, in descending order of frequency. The data show that teenagers today include a set of 22 different types of intensifiers in their daily talk compared to 23 types in the language of youngsters two decades ago. The general type frequency within the paradigm of intensifiers thus remains quite stable.

The exploration of the list of types in each corpus led to a number of interesting observations. First, regarding productivity, the bar charts clearly display the divergence between more frequently used types and low-frequent items. It is noteworthy that the top five of most frequently used intensifiers, i.e., the lexical intensifiers mazo, puto, and to(do) and the morphological intensifiers -ísimo and super-, do not change in terms of composition although it does differ frequency-wise (cf. infra Section 4.3 for more details). Therefore, at first sight, the renewal within the intensifier paradigm in Madrilenian teenage talk does not appear to be as 'fast' and 'dramatic' as generally acknowledged (Aijmer 2018). 
Token frequency per type COLAm

68

${ }^{31} 24$

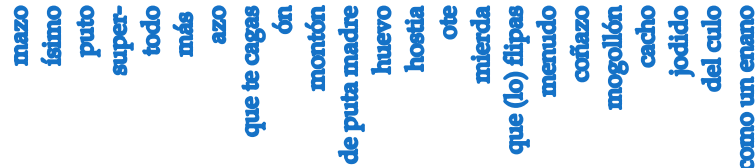

Token frequency per type CORMA

62

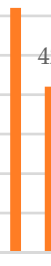

$-4240$

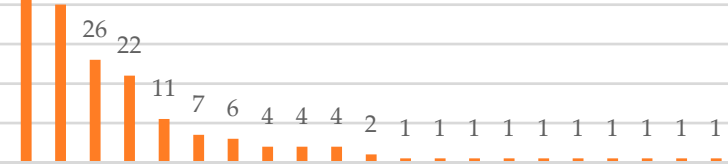

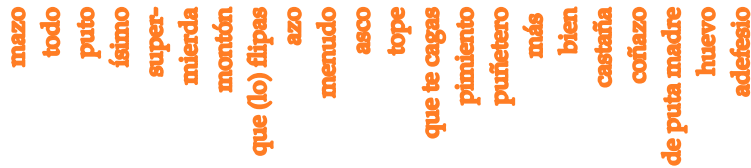

Figure 1. Comparison of the paradigm of morphological and lexical intensifier types in COLAm and CORMA.

In order to acquire a more comprehensive perspective on the analysis of innovation and variability, it is interesting to explore the hapaxes and to appreciate the more marginal members of the paradigm (Zeschel 2012). Hapaxes are items occurring only once in the corpus (Baayen 2009) that might have an impact on the 'potential productivity' of the linguistic phenomenon of intensification. However, taking into account the reduced sample size and the possible strong influence of context-dependent and idiosyncratic language use, they need to be approached with caution. Therefore, in this study, we considered hapaxes as one-offs or types that were not yet observed in the earlier COLAm corpus and accordingly, appeared for the first time and only once in the more recent CORMA corpus. ${ }^{17}$ Five different intensifier hapaxes appear in CORMA (i.e., pimiento, puñetero, castaña, adefesio, bien) ${ }^{18}$ Unsurprisingly, these hapaxes all belong to the more open paradigm of lexical intensifiers. The data thus suggest that hapaxes within the intensifier paradigm are generally of a lexical nature, being the most open class to ad hoc and contextual-dependent innovations. ${ }^{19}$ For instance, the hapax pimiento (me importa a mí un pimiento 'I don't give a damn') appears in this negative context within the open slot of the minimizing construction. ${ }^{20}$ In the case of puñetero (el puñetero $(())^{21}$ 'the bloody $\left.(())^{\prime}\right)$, the meaning and behavior is very similar to puto and to the English intensifier fucking (Palacios Martínez and Núñez Pertejo 2014). The use of other hapaxes like castaña (castaña de niños 'bunch of annoying children') and adefesio (adefesio de persona 'a ridiculous person') seems to be highly dependent on the context. The intensifier bien (bien guapo 'very handsome') comes up as a one-off in our teenage talk corpus. Given its (relative) high frequency in the Madrilenian adult language (Roels and Enghels 2020), it is presumable that teenagers avoid using this intensifier out of a desire to protect their in-group identity (cf. supra Section 1).

Regarding the heterogeneity of the paradigm, we observed intensifiers operating both at the more descriptive level, boosting an inherent property or feature of the modified element, and at the evaluative level, where the intensifier reflected the speaker's emotions and attitudes toward the descriptive content. Degree modification was attested both in a quantitative way (e.g., mazo de pibas 'a lot of girls'; he cambiado un montón 'I changed a lot'; to pequeña 'really small'; muchísimas veces 'many many times') and in a qualitative perspective, boosting the inherent quality of the modified element (e.g., tope de raro 'very strange'; superacogedor 'super cozy'; menudos rivales 'what a rivals'; guapisima 'really pretty'; mazo bien 'very well'). Still, as expressive linguistic units, intensifiers are highly influenced by the personal evaluation of the speaker (cf. supra Section 2). This evaluation can move toward the positive or the negative end of the scale of intensification, ranging from appreciation and positive valuation to disapproval. Hence, an evaluative independent meaning is added to the main descriptive content (Potts 2007). Examples of the former positive heightening are, for instance, planazo 'a great plan', estudié que te cagas 'I studied very well', la mejor puta serie del mundo 'the best fucking series in the world', and me enamoré que flipas 'I fell in 
love like crazy'. The negative expressive force arises with types like una mierda de razón 'a shitty reason', putos animales 'fucking animals', asco del pibe 'disgusting kid', and jodido Vado 'fucking Vado'. As can be inferred from the examples, the same type can operate at different levels.

The internal structure and the origin of the intensifiers are quite diverse. For instance, in the list of types presented in Figure 1, a heterogeneous set of intensifying constructions can be distinguished, recruited from different grammatical categories like prefixes (supermajo 'super cool'), suffixes (equipazo 'a great team'), adjectives (menudos rivales 'what a rivals'), and adverbs (to estresada 'really stressed'). Still, more diversity arises with examples of NPs (un montón de gente 'a heap of people'), (inversed) PPs (cuatro asignaturas de mierda 'four crappy subjects'; mierda de trabajo 'a shitty work'), and even subordinate clauses (una multa que flipas lit. 'a fine that freaks you out'). When they evolve into intensifying mechanisms, the original constructions are recategorized, for instance, by the integration of a VP within an NP, as in the latter example.

\subsection{Stability and Shifts within the Paradigms}

This section highlights some remarkable tendencies in light of recent language changes. To this end, Table 4 provides an overview of the 15 shared intensifier types in the COLAm and CORMA corpora and their overall frequencies. These types are analyzed from a paradigmatic, syntagmatic, and diachronic point of view (Zeschel 2012). As for the paradigmatic dimension, we focused on the distribution and the relative frequencies of the forms within the paradigm of each corpus. From a syntagmatic viewpoint, special attention was paid to the behavior of some intensifiers and to several indexes of grammaticalization, i.e., its contextual expansion and 'position mutability' or "the ease with which it can be shifted around in its context" (Lehmann 2002, p. 140). Diachronically, the origin of the intensifiers is considered to detect possible 'recyclings' from other forms or categories.

Table 4. Comparison of intensifier types occurring in both COLAm and CORMA.

\begin{tabular}{|c|c|c|c|c|c|c|}
\hline \multirow{2}{*}{ Types (15) } & \multirow{2}{*}{$\frac{\text { COLAm }}{\#}$} & \multicolumn{5}{|c|}{ CORMA } \\
\hline & & \# norm. & $\%$ & $\#$ & \# norm. & $\%$ \\
\hline mazo 'really, a lot' & 68 & 14.6 & 35.6 & 62 & 22.2 & 25.8 \\
\hline -ísimo 'very' & 31 & 6.6 & 16.2 & 26 & 9.3 & 10.8 \\
\hline puto 'fucking' & 24 & 5.1 & 12.6 & 40 & 14.3 & 16.7 \\
\hline super- 'super' & 21 & 4.5 & 11 & 22 & 7.9 & 9.2 \\
\hline to $($ do $)$ 'very' & 10 & 2.1 & 5.2 & 42 & 15 & 17.5 \\
\hline más 'most' & 8 & 1.7 & 4.2 & 1 & 0.4 & 0.4 \\
\hline -azo 'nice, great' & 5 & 1 & 2.6 & 4 & 1.4 & 1.7 \\
\hline que te cagas 'extremely, very well' & 4 & 0.9 & 2.1 & 1 & 0.4 & 0.4 \\
\hline montón 'a heap, a lot' & 2 & 0.4 & 1.0 & 7 & 2.5 & 2.9 \\
\hline de puta madre 'fucking great' & 2 & 0.4 & 1.0 & 1 & 0.4 & 0.4 \\
\hline hиеvo 'as shit' & 2 & 0.4 & 1.0 & 1 & 0.4 & 0.4 \\
\hline mierda 'shitty' & 1 & 0.2 & 0.5 & 11 & 3.9 & 4.6 \\
\hline que (lo) flipas 'extremely, like crazy' & 1 & 0.2 & 0.5 & 6 & 2.2 & 2.5 \\
\hline menudo 'what a...' & 1 & 0.2 & 0.5 & 4 & 1.4 & 1.7 \\
\hline coñazo 'a pain in the ass' & 1 & 0.2 & 0.5 & 1 & 0.4 & 0.4 \\
\hline Total & 181 & 38.7 & 94.5 & 229 & 82 & 95.4 \\
\hline
\end{tabular}

The analysis zooms in on the intensifier with the most striking increase (to(do), with an increase of $12.3 \%$ within the paradigm) and on interesting decreases (mazo and -isimo with a respective reduction of $9.8 \%$ and $5.4 \%$ within the intensifying paradigm). The possible motives behind the quite stable productivity of the intensifying prefix super-are also addressed. However, the study does not scrutinize the details of the linguistic change and the grammaticalized status of each type of intensifier, leaving this description for future research. 
Before addressing these prominent tendencies, some general remarks have to be taken into account. First, the fact that a limited set of types is dominant in both paradigms stands out. The previously mentioned 'top five' (cf. supra Section 4.2) covers 80 to $81 \%$ of the total paradigm of both COLAm and CORMA. Second, it seems that the overuse of several forms, for instance, the high frequency of mazo and -ísimo at the beginning of the 21st century, did not lead to attrition nor disappearance in a later phase. Thus, despite the widely spread consensus on the status of intensifiers as rapidly changing linguistic elements, our data do not point to these remarkable shifts. Next, in comparison to the wide range of lexical resources within the intensifying paradigm, particularly two morphological strategies stand, i.e., the suffix -ísimo and the prefix super-. Considering the almost complete absence of paradigmatic variability (Lehmann 1985), it seems as if the Spanish morphological intensifying paradigm has become more grammaticalized than described in the literature (Albelda Marco 2007; García Platero 1997; Rodríguez Ponce 2002). This tendency has strengthened in the intensifying acts of today's Madrilenian youngsters, with an extension of the paradigm of lexical intensifiers in both type and token frequency. Overall, there is still quite a lot of variability within the intensifier paradigm.

Given these general tendencies, let us now take a look at the most frequently used intensifier type mazo, which can be considered a clear marker of young identity (Roels and Enghels 2020). The data from both corpora indicate that, even over a period of more than 15 years, this intensifier remains widespread, although its use decreased considerably in relative terms. It appears that the high frequency of this grammaticalized element at the beginning of the 21st century had an impact on its context expansion, leading to some innovative pragmatic uses in the recent CORMA corpus. For instance, the following example illustrates its new non-conventional function as an affirming element of the previous assertion (see Enghels et al. 2020 for more details and examples):

\section{IR2F20: eee-es una hija de puta ('yeah she's a son of a bitch')}

\section{IR2F19: mazo ('really') (CORMA: IR_AM2_F_09)}

Indeed, mazo can best be described in terms of grammaticalization. It originated as a collective noun (un mazo de cartas 'a pack of cards') and, through a process of semantic bleaching, it lost its full lexical value to express a high degree qualitatively (mazo de chill 'really chill') or quantitatively (mazo dinero 'a lot of money'). It does not only modify adjectives and adverbs, but also nouns and verbs. The data thus suggest that the use of this frequent intensifier is reducing slightly but remains vital within the intensifying acts of Madrilenian teenagers today. Future studies will have to prove if mazo will endure as an intensifier in the longer term or if it will become obsolete and fall 'out of fashion', freeing up space for upcoming forms.

In line with the general decrease in the use of intensifying suffixes by teenagers in the last decades (cf. supra Table 2), the use of the superlative suffix -ísimo decreased as well. Despite the shrink within the paradigm, this more standardized expression of intensification remains widely spread in contemporary teenage talk. It seems that the suffix, which became widespread by virtue of its diffusion in the more cultured language, has lost its former more cultivated status (Lara Bermejo 2017). ${ }^{22}$ For instance, currently, it easily combines with colloquial adjectives and taboo adverbs (e.g., cagadísima 'really fucked up', de putísima madre 'so fucking great').

Next, the lexical type to(do) undoubtedly presents the most striking rise in frequency. As an incoming intensifier, related to the indefinite quantifier todo/toda 'all, every', it has acquired new functions in Spanish teenage talk. Aside from the semantic shift from a totalizing value (e.g., toda su vida 'his whole life') to a degree modifier denoting a higher degree on the scale (to guapo 'very handsome'), the grammaticalization process of this element seems to go hand in hand with its phonetic erosion (todo $>$ to).

If we analyze the occurrences of to (do) in both corpora, some interesting observations can be made. In terms of its contextual expansion, it is noticeable that at the beginning of the 21st century, to(do) only modified adjectives (to pedo 'really drunk'), while today, its 
scope is broadening to adverbs (to bien 'really well') and even exceptionally, a noun (yo tenia to' el miedo 'I was scared to death'). At a more specific level, in seven out of ten cases in which $t o(d o)$ is used as an intensifier in COLAm, the modified adjective relates to the lexical domain of drugs and its subsequent effects (e.g., to sobado/fumada 'very stoned'; to flipado 'really freaked out'; to pedo 'really drunk'). Some of these cases clearly illustrate the ongoing grammaticalization process, with the reading of totality ('entirely') still present:

3. MALCC2J01: ya pero que tenía que estudiar ('yeah but I had to study')

MALCC2J03: has estudiado mucho estos días ('you've been studying a lot these days')

MALCC2J01: al final no he estado toda fumada ('in the end no, I was completely/very stoned')

MALCC2J03: de porros ('of joints') (COLAm: malcc2-14) ${ }^{23}$

Today, Madrilenian teenagers make use of this lexical type to intensify a wide variety of adjectives, corroborating its status as an incoming expanding intensifier. In (4), it combines with the English borrowing cringe.

4. RE2F3: pensaba que iba a decir <ipero eres Claudia?> ('I thought he was going to say $<$ but are you Claudia?>')

RE2M2: ¿eres Claudia o el (())? ('are you Claudia or the (())?')

RE2M1: ostia sería to' to' cringe ('fuck it would be really really cringe') (CORMA: RE_AM2_02)

Alongside these rises and declines in frequency, the prefix super- has kept a rather low profile over the last decades as a more stable, intensifying type in the paradigm. As the only intensive prefix used by Madrilenian teenagers appearing in both COLAm and CORMA, it remains the prefix par excellence to denote a higher degree on the scale (e.g., superguay 'really cool'). The data thus demonstrate a complete absence of paradigmatic variability within the inventory of intensifying prefixes. The morphological intensifier followed a remarkable development, from Latin to contemporary Spanish. In the same vein of other Latin prefixes such as supra-, extra-, and ultra-, super- originally expressed a locative value to acquire a value already intensifying in the 19th century (Rodríguez Ponce 2002; Serradilla Castaño 2018). ${ }^{24}$ However, an apparent time analysis of this specific prefix in CORMA was instructive for the fact that super- is a rather modern prefix of intensification in Madrilenian Spanish (see Roels and Enghels 2020 for more details). Its status as a morphological intensifier probably triggers its consistent frequency over the last few decades, benefiting from its more grammatical and systemic nature as it belongs to a relatively closed paradigm in comparison to the open inventory of lexical items. It appears to be less likely that the younger speakers will abruptly abandon this more system-dependent intensifier. Accordingly, previous studies stressed its sociopragmatic status as a common intensifier in semi-formal upper-middle-class speech (Molina Martos 2010), supporting its more standardized allure. These more neutral semantics and more prestigious recognition seem to favor its fame and vitality in the language of older generations as well (Roels and Enghels 2020).

\section{Monitoring Recent Language Change within the Vocative Paradigm}

\subsection{General Overview}

Generally speaking, the vocative is considered a strikingly productive phenomenon in Spanish teenage language (Jørgensen and Martínez 2009; Stenström 2008), as confirmed by the corpus data. Per 10,000 words, no less than 159 vocatives were uttered by Spanish teens. As shown in Table 5, the normalized frequencies of vocative expressions have almost doubled over the last two decades. 
Table 5. Normalized frequency of vocatives per corpus.

\begin{tabular}{ccc}
\hline & \# Absolute & \# Normalized \\
\hline COLAm & 607 & 129.9 \\
CORMA & 586 & 209.7 \\
\hline Total & 1193 & 159.7 \\
\hline
\end{tabular}

According to Jørgensen (2008), the frequent use of vocatives can best be ascribed to a general feeling of insecurity, typical of the adolescent life stage. This prompts young speakers to more actively control and corroborate the contact with their interlocutors than adult speakers do. The data in Table 6 suggest that adolescents preferably appeal to nominal terms of address, and this trend is strengthened in the most recent CORMA corpus.

Table 6. Distribution of general categories of vocatives per corpus.

\begin{tabular}{ccccccccc}
\hline & COLAm & & & CORMA & & \multicolumn{3}{c}{ Total } \\
\hline & \# & \# norm. & \% & $\#$ & \# norm. & \% & \# & \% \\
\hline proper names & 136 & 29.1 & 22.4 & 38 & 13.6 & 6.5 & 174 & 14.6 \\
nominal ToA & 440 & 94.1 & 72.5 & 510 & 182.5 & 87 & 950 & 79.6 \\
2nd-pers. pron. & 31 & 6.6 & 5.1 & 38 & 13.6 & 6.5 & 69 & 5.8 \\
\hline Total & 607 & 129.9 & 100 & 586 & 209.7 & 100 & 1193 & 100 \\
\hline
\end{tabular}

More interesting changes can be observed. While the use of nominal terms of address has increased, the frequency of proper names has dropped significantly, in terms of both relative (from $22.4 \%$ to $6.5 \%$ ) and normalized (from 29.1 to 13.6) frequencies. However, it must be noted that addressing others by using their proper names occurs prototypically in multiparty conversations, where the need to select and identify the intended addressee within the group of interlocutors is much stronger than in one-to-one conversations (Kleinknecht and Souza 2017). That explains why most of the proper name tokens are registered in multiparty conversations in both COLAm and CORMA. ${ }^{25}$

In contrast, the normalized frequencies of the second-person pronoun tú have doubled over the last two decades. Nevertheless, it must be observed that within the vocative paradigm, its relative frequency remains quite stable ( $5.1 \%$ in COLAm vs. $6.5 \%$ in CORMA).

\subsection{Configuration of the Paradigms}

In this section, attention is paid to the vocative types occurring in teenage language and their token frequencies. First, we checked for changes in the cloud of exemplars. Figure 2 gives an overview of the vocative types extracted from the COLAm (upper panel) and CORMA (lower panel) corpuses, in descending order of frequency. ${ }^{26}$ While COLAm presents 36 different types, CORMA contains an inventory of only 26 types, which indicates a decrease in type frequency over the last two decades. However, this decrease does not necessarily involve a general decrease in productivity of the vocative. Indeed, when looking in more detail at the distribution of these types, some interesting developments can be observed.

Overall, the bar charts reveal remarkable differences between the two time periods under study. When looking at frequency differences within each set, a clear distinction can be made between high-frequency and low-frequency items. However, these differences seem to be enhanced within the CORMA paradigm, where tio 'dude' is undoubtedly the 'number one' vocative, leaving the other types a long way behind. The predominance of tio in teenage talk seems to have already started in the 2000s (or before), as shown by the COLAm data, and this trend has only gained force over the last 15 years. One might even say that tio is slightly absorbing the whole paradigm, invading the territory of other (highly) frequent types, such as tronco 'dude'. 


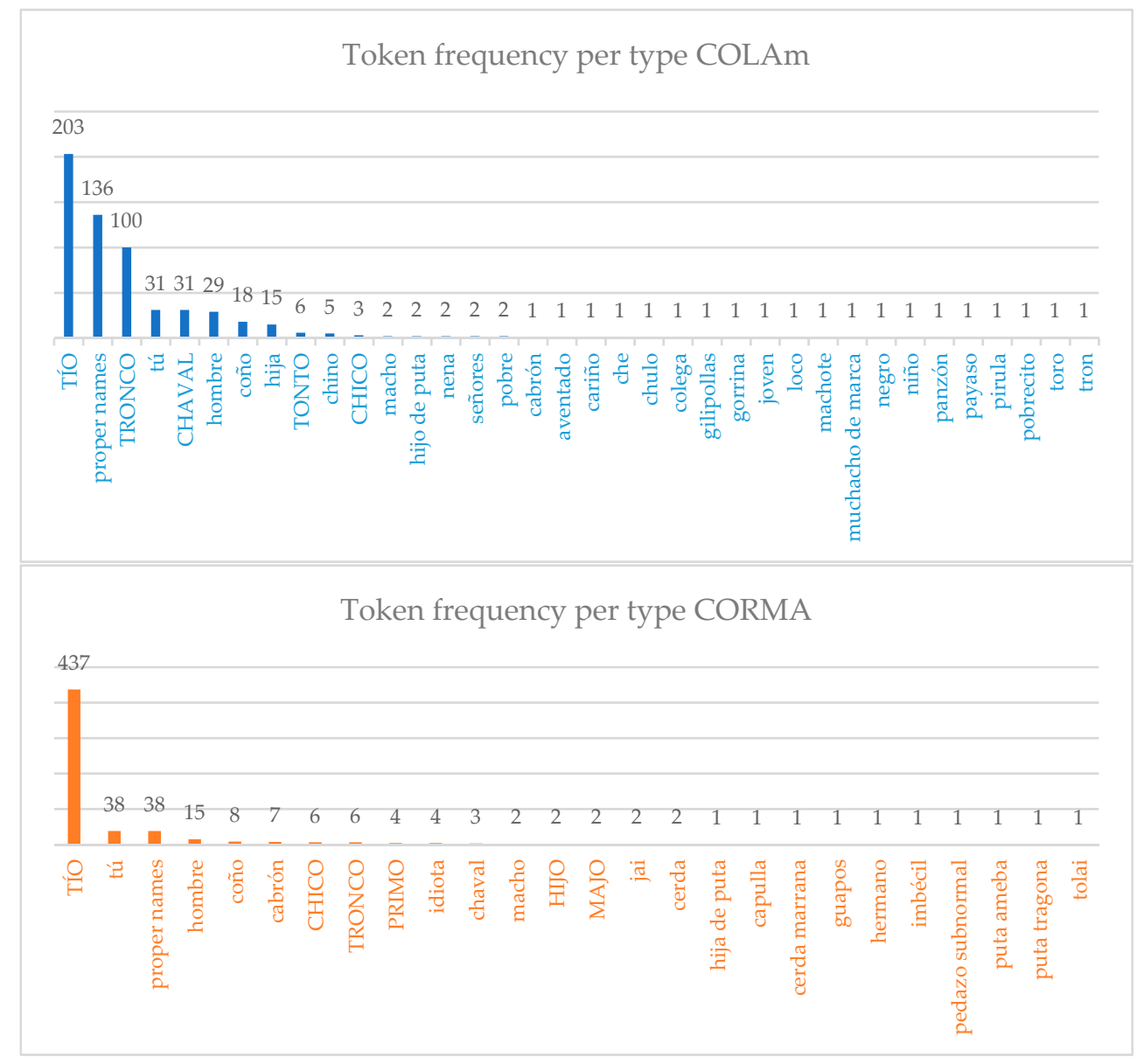

Figure 2. Comparison of the paradigm of vocative types in COLAm and CORMA.

Furthermore, taking into account the 'top five' vocative subset per corpus, some noteworthy shifts can be signaled. While three items from the COLAm top five are maintained in the CORMA top five ( $t$ io, proper names, $t u$ ' $y o u$ '), two types are substituted by other ones, namely tronco and chaval 'boy', which are replaced by hombre 'man' and coño 'pussy'. 27

The most important frequency drop can be observed in the case of tronco, registered 100 times in COLAm (or in 16.5\% of all cases), while only six times (or 1\%) in CORMA. Moreover, the new incoming forms in the top five, hombre and the invective form coño, are frequently used in exclamative structures and are generally considered vocatives with an advanced grammaticalization status (cf. infra Section 5.3). In sum, a first approach to the dataset showed that the renewal within the vocative paradigm occurs relatively fast and at least faster than in the case of intensifiers.

In order to gain insights into the variable and innovative character of the vocative paradigm, it is interesting to explore the hapaxes included in the more recent CORMA corpus. In total, nine different hapaxes, all belonging to the nominal terms of address subcategory and some of them highly idiosyncratic, were found in the CORMA sample, namely capulla 'twit', cerda marrana 'pig', guapos 'beautiful people', hermano 'brother', imbécil 'twit', pedazo subnormal 'freak', puta ameba 'fucking ameba', puta tragona 'fucking gannet', and tolai 'silly'. Remarkably, seven out of the nine items are taboo terms or have at least an invective character, whereas only two of the hapaxes have a conventional positive meaning. However, it has been shown that teenagers make use of taboo and insulting terms as a means of enhancing social bonds to express trust and camaraderie (Stenström 2008). The interpersonal effect on the relationship is called antipoliteness, mock impoliteness, or banter, defined by Leech $(2014$, p. 238) as the case in which "overt impoliteness leads to 
a 'polite' (or rather 'camaraderic') interpretation." In the same line of ideas, all invective hapaxes are interpreted as instances of banter, leading to an enhancement of the social relationships between the interlocutors.

Another hapax of interest is hermano 'brother', considered as a familiarizer that expresses a metaphorical kinship relationship between the interlocutors, comparable to bro in English. Although its English counterpart is considered a highly frequent familiarizer in everyday conversations, in both British and American English (Urichuk and LoureiroRodríguez 2019), hermano is used only once in CORMA, and no occurrences were found in the COLAm sample. In the globalized context of teenage life today, the intensive and daily contact with English may explain the usage of hermano as a calque or loan translation from English into Spanish. Keeping this in mind, hermano has the potential to be used and diffused more extensively within the Spanish youth language in the (near) future. This hypothesis will need further (comparative) research to be corroborated.

In contrast, most of the hapaxes found in the corpus were highly context-dependent and could be considered the speaker's ad hoc reaction to the addressee's (verbal) actions. A meaningful example of this is the hapax puta tragona 'fucking gannet', uttered by a girl who reacts to her friend's choking and coughing:

\section{IR2F16: (drinks water, chokes and coughs loudly)}

IR2F17: hostia tía puta tragona trágatelo yaa (both laugh) ('damn girl fucking gannet swallow it now') (CORMA: IR_AM2_F_08)

Finally, it must be noted that the term of endearment guapos 'beautiful people' is a term of address typically used in spoken Spanish by different age groups (De Latte 2021). Despite its original flattering meaning, it often produces an ironic effect, as observed in (6).

6. MS2F4: pero escúchame a mí nos ha jodido la vida el año pasado y este ('but listen to me he fucked our lives last year and this year')

MS2F3: a mí a mí sí (()) (()) ('mine mine yes (unintelligible)')

MS2M7: y este porque tenemos eh hay una desnivel monumental ('and this year because we have uh there is a huge discrepancy')

MS2F3: eh guapos a mí también ¿vale? ('eh beautiful people mine too right?')

MS2M7: ya maja pero tú primero bachillerato ya vas a ir con un buen nivel a segundo ('right pretty but you the first year in high school you will already go with a good level to the second year') (CORMA: MS_AM2_03)

In (6), two classmates (MS2F4 and MS2M7) are commenting on a teacher they do not like and his negative influence on the students, emphasizing that it was especially hard for their class group. Doing so, they seem to neglect their other friend (MS2F3), who is also participating in the conversation but is no classmate of theirs. This friend (MS2F3) disagrees with the others' statement and, in order to show her annoyance, she attracts the others' attention through the vocative guapos, reminding them that she has also suffered from the teacher's behavior. The negative undertone provoked by the vocative is obviously captured by one of the two addressees (MS2M7), who replies, in turn, by also recurring to a term of endearment with a negative contextual effect, namely maja 'pretty', which clearly contrasts his opinion with that of his friend's.

In sum, since most of the documented hapaxes are taboo or insulting expressions, it can be concluded that this subparadigm is highly productive, in the sense that this particular semantic field delivers various innovative vocative forms.

\subsection{Stability and Shifts within the Paradigms}

If we zoom in on the vocatives occurring in both corpora, Table 7 shows a set of ten matching types, which, however, display some remarkable paradigmatic shifts.

The type tio is by far the preferred vocative expression in both COLAm and CORMA. In the most recent corpus, its relative frequency has more than doubled (74.6\%) in comparison to its paradigmatic weight within the older corpus (33.4\%). Obviously, tio's increase in 
productivity occurs at the expense of all the other types shared by both corpora. In this respect, the item whose frequency has decreased most dramatically is tronco, which is progressively losing territory within the CORMA paradigm, where it has almost disappeared $(1 \%)$. However, some expressions seem to remain quite stable across the datasets, such as $t u$, which stands out within the paradigm due to its grammatical, pronominal nature. The Spanish pronominal address system constitutes a closed, grammatical inventory, as opposed to the open nominal address system, more subject to lexical changes and innovations (cf. infra Section 5.3).

Table 7. Comparison of vocative types occurring in both COLAm and CORMA.

\begin{tabular}{|c|c|c|c|c|c|c|}
\hline \multirow{2}{*}{ Types (11) } & \multirow{2}{*}{$\frac{\text { COLAm }}{\#}$} & \multicolumn{5}{|c|}{ CORMA } \\
\hline & & \# norm. & $\%$ & \# & \# norm. & $\%$ \\
\hline TÍO ‘dude' & 203 & 43.4 & 33.4 & 437 & 156.4 & 74.6 \\
\hline TRONCO 'dude' & 100 & 21.4 & 16.5 & 6 & 2.1 & 1 \\
\hline tú 'you' & 31 & 6.6 & 5.1 & 38 & 13.6 & 6.5 \\
\hline CHAVAL 'boy' & 31 & 6.6 & 5.1 & 3 & 1.1 & 0.5 \\
\hline hombre 'man' & 29 & 6.2 & 4.8 & 15 & 5.4 & 2.6 \\
\hline coño 'pussy' & 18 & 3.9 & 3 & 8 & 2.7 & 1.4 \\
\hline HIJO ‘son' & 15 & 3.2 & 2.5 & 2 & 0.7 & 0.3 \\
\hline CHICO 'kid' & 3 & 0.6 & 0.5 & 6 & 0.7 & 1 \\
\hline macho 'dude' & 2 & 0.4 & 0.3 & 2 & 0.7 & 0.3 \\
\hline HIJO DE PUTA 'son of a bitch' & 2 & 0.4 & 0.3 & 1 & 0.4 & 0.2 \\
\hline cabrón 'bastard' & 1 & 0.2 & 0.2 & 7 & 2.5 & 1.2 \\
\hline Total & 435 & 93 & 71.7 & 525 & 187.8 & 89.6 \\
\hline
\end{tabular}

This section further concentrates on the three aforementioned vocative expressionstio, tronco, and the pronoun tú - as they seem to take highly distinct pathways of linguistic change.

First, it is important to note that the two nominal vocative types are both categorized as familiarizers, defined as vocatives that "mark the relationship between speaker and addressee as a familiar one" (Leech 1999, p. 112). As pointed out by Kleinknecht and Souza (2017), most familiarizers tend to have a neutral semantic meaning, generally referring to (male) individuals or simply 'a person', and usually express a close, trustful, and friendly relationship between the interlocutors. Their redundant and 'marked' character in interaction has repeatedly been underlined in the literature (Rendle-Short 2010). That is, as opposed to prototypical vocatives, i.e., proper names, with the capacity to unequivocally identify addressees within a given context, familiarizers lack this semantic specificity. Their non-specific semantics makes them, in contrast, suitable to be used in multiple contexts. This also explains why familiarizers are usually employed when the addressee has already been identified and why they turn out to be less useful in the prototypical attention-getting function.

Of special interest for this case study is the familiarizers' affective stance marking, considered as one of their core characteristics (Kleinknecht and Souza 2017). Following Ochs' definition (Ochs 1996, p. 410), affective stance is the linguistic expression of "mood, attitude, feeling, and disposition, as well as degrees of emotional intensity vis-à-vis some focus of concern." Importantly, affective stance markers, such as familiarizers, are typically associated with an expressive speech style, and thus closely related to the notion of expressivity. Expressive linguistic tools allow speakers to convey certain attitudes toward the (speech) situation, by signaling a higher degree of emotional involvement of the speaker in the (speech) activity (Kleinknecht and Souza 2017). Importantly, it is considered a central notion in studies of language change and grammaticalization (Hopper and Traugott 1993). As deictic markers explicitly involving the interlocutor in the (speech) activity, familiarizers openly invite the addressee to take part in the emotions and attitudes displayed by the speaker. Cases such as tio and tronco can thus be defined as affective intensifiers of the utterances they combine with. 
Let us first consider tio, the most prominent vocative in both corpora. From a semantic point of view, its meaning has amplified during the course of history. From originally meaning 'uncle, aunt', it developed meanings including 'elder person' and, of special interest here, 'a (specific) individual' (Llopis Cardona and Pons Bordería 2020). Its vocative usage emerged at the beginning of the 1970s, after which the term of address tio widely spread within groups associated with the Spanish Movida, the countercultural movement that took place mainly in Madrid during the Spanish transition after Francisco Franco's death in 1975. However, it quickly surpassed the borders of those clandestine, suburban circles, being picked up by youngsters in the most important Spanish cities, especially Madrid (Llopis Cardona and Pons Bordería 2020). In that stadium of its evolution, tío progressively replaced the leading term of address in informal situations, macho, and its diffusion has not stopped ever since. Moreover, its vocative use is not limited to teenage talk, as it is also a familiarizer commonly used between Spanish adults in daily conversations (Alba-Juez 2009; Jørgensen 2008). At the semantic level, tio obviously has a non-specific, neutral referential meaning, which makes it available in a wide variety of contexts. This may explain its increase in frequency and, according to Llopis Cardona and Pons Bordería (2020), the subsequent amplification of its functional potential, which is also reflected by its versatile distributional characteristics.

Indeed, as observed in previous studies, it is not uncommon that the masculine variant tio is used to address women or even a group of interlocutors. ${ }^{28}$ This phenomenon is referred to as generalization or "fossilization of the masculine singular form" (Kleinknecht and Souza 2017, p. 261). When there is a mismatch between the vocative's morphological form and the addressee's gender, the deictic reference is virtually lost, or at least loosened, and the semantic meaning is bleached in an advanced stage, similar to the general Spanish vocative hombre 'man' (Cuenca and Torres Vilatarsana 2008). Used in its fossilized configuration, tío can be classified as a pragmatic marker of solidarity (Alba-Juez 2009). Interestingly, the frequency of the fossilized uses of tío in both corpora shows some noteworthy trends: COLAm registers only one clear fossilized token of tío (1/95 or $1 \%)$, whereas we found 18 cases (18/107 or $16.8 \%$ ) in CORMA, as illustrated by (7), where tio addresses the group of girlfriends.

7. IR2F25: e-el día de su cumple le dijo esta ah ay dios eh felicidades no sé qué y este se empezó a quejar de que la gente era mazo falsa que le decían-le decía cosas-o sea eso-tio y que se le puso a Carmen eh ('th- the day of his birthday she told him she ah oh god uh congratulations whatever and he began to complain that people are so false and that they told him- he told her things- that is thatdude and that he wrote to Carmen uh-') (CORMA: IR_AM2_F_11)

When we focus on the vocative functions assumed by these fossilized cases, two macro-functions stand out. First, the fossilized vocative is generally used for expressive purposes uttered with an exclamative intonation, eventually in combination with other interjections and exclamatory constructions. In other cases, the vocative functions at a more textual level, signaling the speaker's difficulties in the formulation of the utterance, also manifested by the presence of other formulation markers such as o sea ('that is') (7). This seems to suggest a functional development from deictic addressing uses into more textual, discursive functions.

Then, the vocative tronco was originally associated with the language of the aforementioned Movida (Lázaro Carreter 1979) as well as military and prison slang (Jørgensen and Martínez 2009). Indeed, the most remarkable difference with tío is tronco's more complex semantics, its quasi-exclusive association with the capital, as well as its explicitly argotic and thus low-class connotation. In the 1970s-1980s, tronco was seen as the most argotic vocative (Cianca Aguilar and Gavilanes Franco 2018). As regards its semantics, in its non-vocative uses, tronco literally means 'trunk' or 'torso'. Used as a term of address with the meaning of 'dude', it indexes collocutors' in-group membership, trust, and solidarity. Despite its argotic connotation, during the 1990s-2000s, tronco was widely spread into teenage talk, mainly in the Spanish capital. Its wide diffusion is registered by the COLAm corpus, where it became the second most important vocative, after tío (Stenström 2008; 
Jørgensen and Martínez 2009). In parallel with tío, tronco also displays fossilized uses, as can be observed in (8) where tronco is used toward several girls.

8. MALCC2G02: joder qué frío tronco ('damn it's so cold $d u d e$ ') (COLAm: malcc2-03)

In COLAm, of a total of 69 tokens of tronco, approximately $23.2 \%$ displays fossilization. In CORMA, only one token of the masculine singular form, used toward a girl, was found. Our data even document the phonetically reduced form tron, which confirms its advanced grammaticalized character (Lehmann 1985).

9. MALCC2J03: di di rin ti ti ti

MALCC2G02: voy a fumar allí tron ('I go smoke over there $d u d e^{\prime}$ )

MALCC2J01: y yo chaval ('me too boy') (COLAm: malcc2-03)

In contrast with tío, tronco manifests a more advanced level of fossilization in COLAm, which may be one of the reasons for its obsolescence in recent years. Contrary to Jørgensen and Martínez's (2009) claims that tronco would, within a given time frame, replace tío as the preferred vocative of Spanish teenagers, the most recent data do not support this statement. It seems quite improbable that tronco, quasi obsolete within the CORMA inventory, would regain force, and replace tío in the (near) future.

Finally, let us now turn to the vocative that remained relatively stable when comparing the two corpora, namely the second-person pronoun $t \dot{u} .{ }^{29}$ This term of address belongs to the closed, though complex, pronominal addressing system in Spanish, where $t u$ is the second-person pronoun indexing a symmetrical relationship between the collocutors as opposed to usted, the pronominal marker of asymmetrical power relationships between speaker and addressee, mainly used in formal situations (Fontanella de Weinberg 1999). Interestingly, during the last decades, the use of informal tú has expanded in such a way that it appears in functional contexts earlier assigned to usted (Alba de Diego and Sánchez Lobato 1980). This reconfiguration of the pronominal address paradigm can be linked to the general informalization of present-day interactions (cf. supra Section 1). While pronouns prototypically assume syntactic functions within the sentence, previous studies have highlighted its use as a vocative, mainly specialized in expressive-emphatic functions (Cuenca 2004; Cianca Aguilar and Gavilanes Franco 2018). In (10), the speaker appeals to the vocative tú to emphasize his exclamations qué falso 'how fake' and qué falsedad 'what a lie' while playing a video game with his friends.

10. IR2M4: es que tío es que tío es que de verdad Dani mírate lo del partido que te lo del grupo que te he dicho, anda qué falso tú qué falso qué falso qué falsedad tú aaaa qué risa vete a ajustes de grupo ('it is dude it is dude it is really Dani look to that of the game that you that of the group that I told you, come on how fake you how fake how fake what a lie you aaaa that's so funny go to group settings') (CORMA: IR_AM2_M_02)

Importantly, the use of $t \dot{u}$ as a vocative is not limited to youth speech, as it seems to be a general characteristic of colloquial conversations in Spanish (Moyna 2017). Since it is not related to a specific age group and because of its grammatical, systemic nature, $t u$ might be seen as a generic vocative, which may also explain its quite stable frequency in both corpora (5.1\% in COLAm and 6.5\% in CORMA). Moreover, it is highly probable that tú was already used for vocative purposes in prior generations' speech (Cianca Aguilar and Gavilanes Franco 2018).

\section{Discussion and Conclusions}

The above analysis leads to a number of interesting conclusions at both a descriptive and theoretical level. First, as regards the general tendencies, it was observed that the use of intensifiers and vocatives has increased considerably in youth speech in the last two decades. For both phenomena, the normalized frequencies have almost doubled when comparing the earlier COLAm and later CORMA corpora. This impressive diffusion 
may be linked to the colloquialization process teenage interaction has been and is still undergoing. Due to the more intensive use of mediated conversation (cf. supra Section 1), their interactions become more informal and expressive. Moreover, one would assume that, given the omnipresence of social media in youngsters' daily life, new 'catchy' items spread quicker than before. However, the data suggest that the speed of change within the intensifier and vocative paradigm is not as dramatic as the literature suggests. As opposed to some claims made in previous studies (cf. supra Section 2), the empirical monitoring of the vocative and intensifier paradigms suggests that in a time frame of 15 years-including a generational shift between the late millennials and the generation $Z$ - there is no tabula rasa of the vocative nor intensifier paradigm. Quite the opposite picture emerges, and many forms used at the beginning of the 21st century have been maintained until now. Hence, changes occur at a more moderate and gradual rate than commonly assumed.

Aside from these general tendencies, the speed and nature of the change of both phenomena seem to correlate with two general principles. On the one hand, the more neutral and standardized forms of the paradigm remain quite stable over time. This has been observed for the intensifiers super-, and to a lesser extent-ísimo, and for the pronominal vocative $t u$. Although these forms might display some slight frequency changes, these fluctuations are never dramatic. On the other hand, the more lexical and expressive types are more quickly engaged in a process of action-reaction, and these often highly frequent terms become a victim of their own popularity. This is confirmed by the gradual replacement of the intensifier mazo by to(do), and the still-growing dominance of tio, which pushes 'older' forms such as tronco toward the periphery of the paradigm. Thus, the inherent expressive nature of an item does play an important part in the nature of recent language change, which in fact, is not unexpected. Highly expressive items contribute the most to the creation of the in-group identity of young speakers. Because of their prominence and distinctiveness within the paradigm, they tend to be picked up faster by other generations, partly through social media but also within the family context and, in the end, are abandoned more quickly by their procreators.

Still, a remarkable result of our study is that this process of change does not seem to occur faster in the case of intensifiers than of vocatives. When comparing the composition of their paradigms in the two corpora, it appears that changes in the vocative paradigm occur at a higher speed than in the intensifier paradigm. Indeed, as mentioned before, in a period of 15 years, we can observe the obsolescence of a formerly highly productive vocative (tronco), almost completely substituted by tio, whereas in the case of the intensifiers, we observe the co-existence of different productive types like mazo and to(do). As to the renewal within their paradigms, both phenomena thus seem to be situated within another phase.

Different motives may lay behind these differences. First, the more rapid turnover within the vocative paradigm can be associated with the intersubjective nature of the phenomenon, which adds to its inherent expressivity and stance marking. As it is particularly important within a community to address peers by a specific in-group term of address, this may explain the urge to create new in-group terms of address when other forms have become less exclusive. A second possible explanation lies in the different structural statuses of both intensifiers and vocatives. The latter have a more clause-external status than intensifiers as they prototypically operate in the periphery of an utterance (cf. supra Section 2). As syntactic 'outsiders', they are more subjected to (functional-pragmatic) changes, following general tendencies of grammaticalization (e.g., Heine 2013). By contrast, intensifiers are more embedded in the sentence with scope over the modified element (cf. supra Section 2). Furthermore, although intensifiers are typically linked to an open inventory of lexical items, the paradigm also includes morphological items pertaining to a systemic and closed paradigm. These observations make it clear that, although both phenomena operate at the lexical level, the personal or interpersonal nature does play a role in (recent) language change.

However, it should be mentioned that the applied real-time methodology has its limits. The comparative corpus analyses provide a rather static image of dynamic processes 
of language change, which might be in a different state of their evolution. Finally, it is probable that different phenomena, such as intensifiers and vocatives, but also pragmatic markers, taboo words, or borrowings, compete with each other as typical markers or in-group expressions of adolescent speech at a particular moment in time. It is clear that the pragmatic marker en plan (the equivalent of the English marker like) and tio can be considered typical teenage expressions today, whereas an intensifier like mazo played that role more properly at the beginning of the century.

Author Contributions: Conceptualization, L.R., F.D.L. and R.E.; methodology, L.R., F.D.L. and R.E.; software, L.R., F.D.L. and R.E.; validation, L.R., F.D.L. and R.E.; formal analysis, L.R., F.D.L. and R.E.; investigation, L.R., F.D.L. and R.E.; resources, L.R., F.D.L. and R.E.; data curation, L.R., F.D.L. and R.E.; writing - original draft preparation, L.R., F.D.L. and R.E.; writing—review and editing, L.R., F.D.L. and R.E.; visualization, L.R., F.D.L. and R.E.; supervision, R.E.; project administration, L.R., F.D.L. and R.E.; funding acquisition, L.R., F.D.L. and R.E. All authors have read and agreed to the published version of the manuscript.

Funding: This research was funded by Research Foundation Flanders (FWO) grant number [FWO.3F0.2019.0017.01].

Institutional Review Board Statement: The study was conducted according to the guidelines of the Declaration of Helsinki, and approved by the Institutional Review Board (or Ethics Committee) of the Faculty of Arts and Philosophy of Ghent University (13 January 2019).

Informed Consent Statement: Informed consent was obtained from all subjects involved in the study.

Conflicts of Interest: The authors declare no conflict of interest.

\section{Appendix A}

\begin{tabular}{lll}
\hline Intensifiers TYPE & Literal Translation & Idiomatic Translation \\
\hline adefesio & hideous & butt-ugly \\
asco & nausea & disgusting \\
-azo & huge, massive & nice, great \\
bien & well & really \\
cacho & piece, slice & bloody \\
castaña & chestnut & annoying \\
como un enano & like a dwarf & a lot \\
coñazo & big pussy & a pain in the ass \\
de puta madre & mother i like to fuck/milf & fucking great \\
del culo & from the head to the ass & really, absolutely \\
hostia & communion waffer & awful, amazing \\
huevo & egg & a lot, as shit \\
-ísimo & very & very, really \\
jodido & messed up & fucking \\
más & more & really \\
mazo & big hammer & really, a lot \\
menudo & small & what a ... \\
mierda & shit & shitty \\
mogollón & a lot & a shitload, loads \\
montón & a pile & a lot \\
-ón & big, large & awful, nice \\
-ote & big, large & huge \\
pimiento & pepper & a damn \\
puñetero & annoying & bloody \\
puto & whore & fucking \\
que (lo) flipas & that freaks you out, like crazy & extremely \\
que te cagas & that you shit yourself & extremely, very well \\
super- & super & super \\
to(do) & whole & very \\
tope & limit & very, really \\
\hline & & \\
\hline & &
\end{tabular}




\begin{tabular}{lll}
\hline Vocatives TYPE & Literal Translation & Idiomatic Translation \\
\hline aventado & brave & brave \\
cabrón & male goat & bastard \\
capulla & cocoon & prick, stupid, idiot \\
cariño & darling & darling \\
cerda & sow & dirty woman, slut \\
cerda marrana & sow sow & dirty woman, slut \\
chaval/chavala & boy/girl & lad/lass \\
che & hey, listen & hey, listen \\
chico/chica & boy/girl & kid/girl \\
chino & Chinese & fool, strange \\
chulo & cool, pimp & cool, pimp, dude \\
\hline
\end{tabular}

\section{Notes}

1 See also the role of Madrid's youth, and in particular, la Movida Madrileña in the years after Franco's death (e.g., (Algaba Pérez 2020)).

2 In this paper, the concept of 'teen language' is defined as the language spoken by teenagers between 12 years (the start of adolescence) and 18 years (when adolescents become legally major in most countries) (Eisenstein 2005).

3 It goes without saying that both phenomena are situated at the interface with syntax and pragmatics, but in this study we are mostly interested in their use as lexical strategies.

4 Example taken from the Corpus Oral de Madrid (CORMA) (cf. Section 3). Each speaker received a codified name according to different variables. The initial letters refer to the communicative context (e.g., AM = amigos ('friends'), PEL = peluquería ('hair salon')) or the educational institution where the teenagers were recruited (e.g., in this case RE). The first number gives more information about the generation to which the speaker belongs (e.g., $2=$ Gen2: $12-25$ y; $3=$ Gen3: $26-55$ y; for more details, see Section 3). The following letter informs about the gender (e.g., $\mathrm{M}=$ male, $\mathrm{F}=$ female) and the last number (e.g., 7 in RE2F7) indicates that the speaker was the seventh female speaker of the second generation of her specific school to participate in the recordings.

5 Rodríguez González (2002, pp. 47-48) refers to the obsolescence of certain terms of address under specific sociopolitical circumstances, especially those expressing deference such as don ('sir'), which are substituted by other, more informal terms of address, such as the second person pronoun tú (at the expense of formal usted) and the nominal terms amiga ('friend'), mujer ('woman'), and compañera ('colleague, buddy').

6 It is noteworthy that, from a generational viewpoint, the participants from COLAm are (late) Millennials, born between 1980 and 1996, while the youngsters from CORMA belong to Generation Z, born between 1996 and today (Dimock 2019). This implies that the data under analysis document a generational shift.

7 The concept of intensifiers often embraces all expressions of degree modification, both scaling upwards and downwards from an assumed norm (Quirk et al. 1985). In this study, we only considered intensifiers that increase the degree or expressive power of the modified item.

8 Note that the scope is not restricted to cases in which the modified element is an adjective (i.a. (Aijmer 2018; Bauer and Bauer 2002; Lorenz 2002; Tagliamonte 2008)) but also includes other categories such as adverbs, nouns, and verbs. For more details on this broader scope, see Roels and Enghels 2020.

9 In some languages, vocatives are morphologically marked as a case through affixation or declension, as for instance in Latin (Janson 2013). However, its case status has been debated because of its particularities which differentiate the vocative from the other canonical cases: as extra-predicative constituents, vocatives are not governed by a verb or a preposition, and from a morphological angle, they tend to lack case markings in most modern languages, including Spanish (Daniel and Spencer 2009; Moyna 2017). This explains why the phenomenon is most properly defined as a pragmatic-functional category and no longer as a case.

10 The sample selected for this comparative study only includes the speech of adolescents ranging from 13 to 19 years old.

11 As the number of words of the selected conversations was not equal for COLAm and CORMA with, respectively, 46,744 and 27,949 words, the frequency was proportionally calculated per 10,000 in each subcorpus.

12 More specifically, in COLAm, we selected four multiparty (32,107 words) and six one-to-one conversations (14,637 words), while in CORMA, six multiparty conversations (16,353 words) were chosen, as opposed to three one-to-one interactions (11,596 words).

13 The identification of the vocative expressions is guided by a number of well-established formal operational criteria: (1) the vocative's extra-propositional and non-argument (thus optional) status; (2) its prosodic autonomy, that is, set-off from the rest of the clause by pauses; and (3) their optional combination with other vocatives or pragmatic markers.

14 In addition to these general linguistic variables, we also took into account relevant sociolinguistic variables such as (1) speaker's gender (male, female), (2) addressee's gender (male, female) in case of the intersubjective vocatives, or (3) neighborhood, as 
further indication of the social class they belong to (Meyerhoff 2006). Note, however, that a detailed account of the impact of these extralinguistic variables exceeds the boundaries of this paper and is kept for a follow-up study.

A previous study conducted in the entire CORMA corpus (thus, data of all generations) showed a quite different picture, with suffixation as the most frequent strategy $(n=245 ; 55 \%)$ followed by lexical items $(n=131 ; 29 \%)$, and prefixation $(n=70 ; 16 \%)$ (Roels and Enghels 2020).

16 The types are considered as morphological or lexical items that can fulfill the linguistic function of intensification. However, one type might include morphological (e.g., -azo, -aza) or syntactic (tope pesado/el tope de raro) variation.

17 We consider the one-offs as signs of creative language use within the corpus, which does not necessarily mean that those one-offs/forms could not have existed in an earlier language stage outside of our corpora. We are well aware of the fact that a comparative corpus study based on two samples has its limits. Needless to say, the fact that a vocative or intensifier does not occur in a corpus does not necessarily mean that it is non-existent in language.

In Appendix A, the two tables present both the literal and the idiomatic meaning of, respectively, the intensifiers and vocatives under scrutiny.

Bearing in mind the small sample, it is still noteworthy that the five observed one-offs were all produced by female teenagers.

In the minimizing construction, the negation denotes the absence of a minimal quantity and hence the presence of no quantity at all (Horn 1989).

21 Due to overlaps and interruptions, the young girl cannot complete her sentence. However, the context guides the analysis toward the interpretation of the modification of a noun: MS2F3 Obviamente iba a faltar el puto viernes porque me tenía que ir hasta tomar por culo para el sábado tener el puñetero (()) hm-de la com-compe-MS2M7 A un amigo mío [ ... ]. The fact that an analogic intensifying mechanism (el puto viernes 'fucking Friday') precedes in the left context strengthens this analysis.

The canonical synthetic superlative derives from the Latin form -issimus. In medieval Spanish, the form disappeared but was reincorporated in classical Spanish (Serradilla Castaño 2018).

Example extracted from the Corpus Oral de Lenguaje Adolescente de Madrid (COLAm) (cf. supra Section 3). Parallel to CORMA, the codified names in COLAm also display different social variables. The initial letters reflect the social class of the speaker (e.g., MALCC in this particular case indicates a lower-class teenager of a particular school that received this code), followed by the number of the recorded conversation (e.g., 2). The next letter informs about the gender (e.g., $G=$ male and $J=$ female), and finally, the last number denotes, for instance in this case, the second male speaker of the MALCC school involved in this specific conversation.

24 The spatial meaning of 'being beyond or over a given point in space' was metaphorically reinterpreted as 'being higher in gradation than a given point' (Napoli and Ravetto 2017).

In COLAm, no less than $93.4 \%(n=127)$ of the total number of proper names are uttered in multiparty conversations, while in CORMA, this tendency levels up to $97.4 \%(n=37)$. This clearly confirms the functional specialization of proper names of identifying and selecting unique addressees, thanks to its semantic specificity.

26 The capital letters in the figures represent the lemmas of the different vocative types included in the paradigm. These include distinct morphological variants. For instance, TÍO is the lemma that refers to all generic and numeric variants (tio(s), tía(s)). Moreover, since all proper names share the same semantic-pragmatic characteristics, including their semantic specificity and unique deictic potential to individualize addressees, they are treated as one type.

Although coño cannot be considered a prototypical term of address given its non-human referential meaning ('pussy'), coño as well as many other more or less grammaticalized forms display a multifunctional behavior, which makes the interpretation of its deictic anchoring very tenuous at times. Still, from a methodological viewpoint, it is pertinent to include also more grammaticalized vocative markers such as coño or hombre ('man', also used toward women or a group of interlocutors), also because of their interactive functions, similar to more prototypical vocatives.

28 Nevertheless, it should be highlighted that the feminine singular form tía is still the default variant to be used toward girls, and all feminine singular tokens are, without exception, used toward a girl, in both COLAm $(\mathrm{n}=106 ; 52.2 \%$ of all tio tokens) and CORMA ( $\mathrm{n}=328 ; 75.1 \%$ of all tío tokens).

29 Spanish is a pro-drop language, which implies that the use of the subject pronoun is optional (Bernal 2007). According to the criteria applied for the selection of vocatives in this study, the tú-vocatives fulfill the following characteristics: they (1) are extra-propositional and non-argumental, (2) display prosodic autonomy, and (3) may be combined with other vocatives or pragmatic particles, and even verbs that are not in the second-person singular.

\section{References}

Aarts, Bas, Joanne Close, Geoffrey N. Leech, and Sean Wallis, eds. 2013. The Verb Phrase in English. Investigating Recent Language Change with Corpora. Cambridge: Cambridge University Press.

Aijmer, Karin. 2018. That's well bad: Some new intensifiers in spoken in British English. In Corpus Approaches to Contemporary British English. Edited by Vaclav Brezina, Robbie Love and Karin Aijmer. New York and London: Routledge, pp. 60-95. 
Alba de Diego, Vidal, and Jesús Sánchez Lobato. 1980. Tratamiento y juventud en la lengua hablada. Aspectos sociolingüísticos. Boletín de la Real Academia Española 60: 95-130.

Alba-Juez, Laura. 2009. 'Little words' in small talk: Some considerations on the use of the pragmatic markers man in English and macho/tio in Peninsular Spanish. In Little Words. Their History, Phonology, Syntax, Semantics, Pragmatics and Acquisition. Edited by Ronald P. Leow, Hector Cámpos and Donna Lardiere. Washington, DC: Georgetown University Press, pp. 171-81.

Albelda Marco, Marta. 2007. La Intensificación como Categoría Pragmática: Revisión y Propuesta: Una Aplicación al Español Coloquial. Frankfurt am Main: Peter Lang.

Algaba Pérez, Blanca. 2020. A propósito de la Movida madrileña: Un acercamiento a la cultura juvenil desde la Historia. Revista de Historia Contemporánea 21: 319-29. [CrossRef]

Arce Castillo, Ángela. 1999. Intensificadores en español coloquial. Anuario de Estudios Filológicos 22: 37-48.

Athanasiadou, Angeliki. 2007. On the subjectivity of intensifiers. Language Sciences 29: 554-65. [CrossRef]

Baayen, Rolf Harald. 2009. Corpus linguistics in morphology: Morphological productivity. In Corpus Linguistics. An International Handbook. Edited by Anke Lüdeling and Merja Kytö M. Berlin: Mouton, pp. 900-19.

Bauer, Laurie, and Winifred Bauer. 2002. Adjective boosters in the English of young New Zealanders. Journal of English Linguistics 30: 244-57. [CrossRef]

Baumgarten, Nicole. 2021. Love as a term of address in British English: Micro-diachronic variation. Contrastive Pragmatics 1: 1-28. [CrossRef]

Bernal, Nuria. 2007. Funciones pragmalingüísticas del pronombre personal sujeto tú en el discurso conflictivo del español coloquial. Revista Internacional De Lingüística Iberoamericana 5: 183-99.

Blanco-Suárez, Zeltia. 2010. On the Origin and Grammaticalisation of the Intensifier Deadly in English. Paper presented at Langwidge Sandwidge, Manchester, UK, October 12.

Blas Arroyo, José Luis. 2005. Sociolingüística del Español: Desarrollos y Perspectivas en el Estudio de la Lengua Española en Contexto Social. Madrid: Cátedra.

Bolinger, Dwight. 1972. Degree Words. The Hague and Paris: Mouton.

Brandimonte, Giovanni. 2011. Breve estudio contrastivo sobre los vocativos en el español y el italiano actual. In Del Texto a la Lengua: La Aplicación de los Textos a la Enseñanza-Aprendizaje del Español L2-LE. Edited by Javier de Santiago-Guervós, Hanne Bongaerts, Jorge Juan Sánchez Iglesias and Marta Seseña Gómez. Salamanca: Asociación para la Enseñanza del Español como Lengua Extranjera, pp. 249-62.

Braun, Friederike. 1988. Terms of Address. Berlin, New York and München: Mouton de Gruyter.

Briz Gómez, Antonio. 1998. El español Coloquial en la Conversación: Esbozo de Pragmagramática. Barcelona: Ariel.

Bybee, Joan. 2003. Mechanisms of change in grammaticization: The role of frequency. In The Handbook of Historical Linguistics. Edited by Brian D. Joseph and Richard D. Janda. Oxford: Blackwell Publishing Ltd., pp. 602-23.

Bybee, Joan. 2010. Language, Usage and Cognition. Cambridge: Cambridge University Press.

Cameron, Richard. 2011. Age, aging and sociolinguistics. In The Handbook of Hispanic Sociolinguistics. Edited by Manuel Díaz-Campos. Oxford: Willey-Blackwell, pp. 207-29.

Catalá Torres, Natalia. 2002. Consideraciones acerca de la pobreza expresiva de los jóvenes. In El Lenguaje de los Jóvenes. Edited by Félix Rodríguez González. Barcelona: Ariel, pp. 123-36.

Cianca Aguilar, Elena, and Emilio Gavilanes Franco. 2018. Voces y expresiones del argot juvenil madrileño actual. Círculo De Lingüística Aplicada a La Comunicación 74: 147-68. [CrossRef]

Cuenca, Maria Josep, and Marta Torres Vilatarsana. 2008. Usos de hombre/Home y mujer/dona como marcadores del discurso en la conversación colloquial. Verba 35: 235-56.

Cuenca, María Josep. 2004. El receptor en el text: El vocatiu. Estudis Romànics 26: 39-64.

Daniel, Michael, and Andrew Spencer. 2009. The vocative: An outlier case. In The Oxford Handbook of Case. Edited by Andrej Malchukov and Andrew Spencer. Oxford: Oxford University Press, pp. 626-34.

De Latte, Fien. 2021. 'Hola guapa, ¿cómo estás?': Usos vocativos del adjetivo de belleza guapo en el español peninsular contemporáneo. Oralia 24: 27-54.

Dimock, Michael. 2019. Defining generations: Where Millennials end and Generation Z begins. Pew Research Center 17: 1-7.

Eisenstein, Evelyn. 2005. Adolescência: Definições, conceitos e critérios. Adolesc Saude 2: 6-7.

Enghels, Renata, Fien De Latte, and Linde Roels. 2020. El Corpus Oral de Madrid (CORMA): Materiales Para El Estudio (Socio) Lingüístico Del Español Coloquial Actual. Zeitschrift fur Katalanistik 33: 45-76.

Fontanella de Weinberg, María Beatriz. 1999. Sistemas pronominales de tratamiento usados en el mundo hispánico. In Gramática Descriptiva de la Lengua Española. Edited by Ignacio Bosque and Violeta Demonte. Madrid: Espasa-Calpe, vol. 1, pp. $1399-426$.

García Dini, Encarnación. 1998. Algo más sobre el vocativo. In Lo Spagnolo d'oggi: Forme Della Comunicazione (Atti del XVII Convegno AISPI). Roma: Bulzoni, vol. 2, pp. 57-62.

García Palacios, Joaquín, Goedele De Sterck, Daniel Linder, Nava Maroto García, Miguel Sánchez Ibáñez, and Jesús Torres del Rey, eds. 2016. La Neología en las Lenguas Románicas. Recursos, Estrategias y Nuevas Orientaciones. New York: Peter Lang.

García Platero, Juan Manuel. 1997. Sufijación apreciativa y prefijación intensiva en español actual. Lingüística Española Actual 19: 51-61.

Grandi, Nicola. 2017. Intensification processes in Italian. In Exploring Intensification: Synchronic, Diachronic E Cross-Linguistic Perspectives. Edited by Maria Napoli and Miriam Ravetto. Amsterdam and Philadelphia: John Benjamins, pp. 55-77. 
Gutzmann, Daniel. 2019. The Grammar of Expressivity. Oxford: Oxford University Press.

Haverkate, Henk. 1994. La cortesía Verbal. Estudio Pragmalingüístico. Madrid: Gredos.

Heine, Berndt. 2013. On discourse markers: Grammaticalization, pragmaticalization, or something else? Linguistics 51: $1202-47$. [CrossRef]

Hilpert, Martin. 2013. Constructional Change in English: Developments in Allomorphy, word Formation, and Syntax. Cambridge: University Press.

Hilte, Lisa, Reinhild Vandekerckhove, and Walter Daelemans. 2018. Expressive markers in online teenage talk. Nederlandse taalkunde 23: 293-323. [CrossRef]

Himmelmann, Nikolaus. 2004. Lexicalization and grammaticalization: Opposite or orthogonal? In What Makes Grammaticalization: A Look from Its Fringes and Its Components. Edited by Walter Bisang, Nikolaus Himmelmann and Björn Wiemer. Berlin: De Gruyter, pp. 19-40.

Hopper, Paul, and Elizabeth Closs Traugott, eds. 1993. Grammaticalization. Cambridge: CUP.

Horn, Laurence. 1989. A Natural History of Negation. Standford: CSLI Publications.

Janson, Tore. 2013. Vocative and the grammar of calls. In Vocative! Addressing between System and Performance. Edited by Barbara Sonnenhauser and Patricia N. Aziz Hanna. Berlin: De Gruyter Mouton, pp. 219-34.

Jenkins, Henry. 2009. Confronting the Challenges of Participatory Culture: Media Education for the 21st Century. Cambridge: MIT Press.

Jørgensen, Annette Myre, and Eli-Marie Drange. 2012. La lengua juvenil de las metrópolis Madrid y Santiago de Chile. Arena Romanistica 9: 74-96.

Jørgensen, Annette Myre, and Juan Antonio Martínez. 2009. 'Tronco/a' usado como marcador discursivo en el lenguaje juvenil de Madrid. In Actas del II Congreso de Hispanistas y Lusitanistas Nórdicos. Edited by Lars Fant, Johan Falk and María Bernal. Stockholm: Acta Universitatis Stockholmiensis, pp. 67-80.

Jørgensen, Annette Myre. 2007. COLA: Un corpus oral de lenguaje adolescente. Oralia 3: 225-34.

Jørgensen, Annette Myre. 2008. Tío y tía como marcadores en el lenguaje juvenil de Madrid. In Actas del XXXVII Simposio Internacional de la Sociedad Española de Lingüística (SEL). Edited by Inés Olza Moreno, Manuel Casado Valverde and Ramón González Ruiz. Pamplona: Universidad de Navarra, pp. 387-96.

Jørgensen, Annette Myre. 2013. Spanish teenage language and the COLAm corpus. Bergen Language and Linguistics Studies 3: 151-66. [CrossRef]

Kleinknecht, Friederike, and Miguel Souza. 2017. Vocatives as a source category for pragmatic marker. From deixis to discourse marking via affectivity. In Pragmatic Markers, Discourse Markers and Modal Particles. New Perspectives. Edited by Chiara Fedriani and Andrea Sansó. Amsterdam and Philadelphia: John Benjamins, pp. 257-87.

Kleinknecht, Friederike. 2013. Mexican güey—From vocative to discourse marker: A case of grammaticalization? In Vocative! ADDRESSING between System and Performance. Edited by Barbara Sonnenhauser and Patricia N. Aziz Hanna. Berlin: De Gruyter Mouton, pp. 235-68.

Kluge, Bettina, and María Irene Moyna. 2019. It's Not All about You: New Perspectives on Address Research. Amsterdam: John Benjamins.

König, Ekkehard. 2017. The comparative basis of intensification. In Exploring Intensification: Synchronic, Diachronic E Cross-Linguistic Perspectives. Edited by Maria Napoli and Miriam Ravetto. Amsterdam and Philadelphia: John Benjamins, pp. 15-32.

Labov, William. 2007. Transmission and Diffusion. Language 83: 334-87. [CrossRef]

Landone, Elena. 2009. Los Marcadores del Discurso y la Cortesía Verbal en Español. Bern: Peter Lang.

Lara Bermejo, Víctor. 2017. El superlativo absoluto en el español peninsular del siglo XX. Rilce. Revista de Filología Hispánica 34: 225-39. [CrossRef]

Lázaro Carreter, Fernando. 1979. Una jerga juvenil: 'el cheli'. ABC 16: 118.

Leech, Geoffrey N. 1999. The distribution and functions of vocatives in American and British English conversation. In Out of corpora: Studies in honour of Stig Johansson. Edited by Hilde Hasselgård and Signe Oksefjell. Amsterdam: Rodopi, pp. 107-18.

Leech, Geoffrey N. 2014. The Pragmatics of Politeness. Oxford Studies in Sociolinguistics. New York: Oxford University Press.

Lehmann, Christian. 1985. Grammaticalization: Synchronic variation and diachronic change. Lingua Stile 20: 303-18.

Lehmann, Christian. 2002. Thoughts on Grammaticalization. Erfurt: Seminar für Sprachwissenschaft der Universität.

Llopis Cardona, Ana, and Salvador Pons Bordería. 2020. La gramaticalización de macho y tío/a como ciclo semántico-pragmático. Círculo De Lingüística Aplicada a La Comunicación 82: 151-64. [CrossRef]

Lorenz, Gunter. 2002. Really worthwhile or not really significant? A corpus-based approach to the delexicalization and grammaticalization of intensifiers in Modern English. In New Reflections on Grammaticalization. Edited by Ilse Wischer and Gabriele Diewald. Amsterdam: John Benjamins, pp. 143-61.

Macaulay, Ronald. 2006. Pure grammaticalization: The development of a teenage intensifier. Language Variation and Change 18: 267-83. [CrossRef]

Meyerhoff, Miriam. 2006. Introducing Sociolinguistics. London: Routledge.

Molina Martos, Isabel. 2010. Difusión social de una innovación lingüística: La intensificación en el habla de las jóvenes madrileñas. Oralia 13: 197-214.

Moyna, María Irene. 2017. Voseo vocatives and interjections in Montevideo Spanish. In Contemporary Advances in Theoretical and Applied Spanish Linguistic Variation. Edited by Colomina Alminana and Project Muse. Columbus: Ohio State University Press, pp. 124-47. 
Napoli, Maria, and Miriam Ravetto. 2017. Ways to intensify: Types of intensified meanings in Italian and German. In Exploring Intensification: Synchronic, Diachronic E Cross-Linguistic Perspectives. Edited by Maria Napoli and Miriam Ravetto. Amsterdam and Philadelphia: John Benjamins, pp. 327-52.

Ochs, Elinor. 1996. Linguistic resources for socializing humanity. In Rethinking Linguistic Relativity. Edited by John J. Gumperz and Stephen C. Levinson. Cambridge: CUP, pp. 407-38.

Palacios Martínez, Ignacio, and Paloma Núñez Pertejo. 2014. Strategies used by English and Spanish teenagers to intensify language: A contrastive corpus-based study. Spanish in Context 11: 175-201. [CrossRef]

Pichler, Heike. 2010. Methods in discourse variation analysis: Reflections on the way forward. Journal of Sociolinguistics 14: 581-608. [CrossRef]

Potts, Christopher. 2007. The expressive dimension. Theoretical Linguistics 33: 165-97. [CrossRef]

Quirk, Randolph, Sidney Greenbaum, Geoffrey N. Leech, and Jan Svartvik. 1985. A Comprehensive Grammar of the English Language. New York: Longman.

Rendle-Short, Johanna. 2010. Mate as a term of address in ordinary interaction. Journal of Pragmatics 42: 1201-18. [CrossRef]

Rodríguez González, Félix, ed. 2002. El Lenguaje de los Jóvenes. Barcelona: Ariel.

Rodríguez Ponce, María Isabel. 2002. La Prefijación Apreciativa en Español. Cáceres: Universidad de Extremadura.

Rodríguez, González Félix, and Anna-Brita Stenström. 2011. Expressive Devices in the Language of English-and Spanish-Speaking Youth. Revista Alicantina de Estudios Ingleses 24: 235-56. [CrossRef]

Roels, Linde, and Renata Enghels. 2020. Age-Based Variation and Patterns of Recent Language Change: A Case-Study of Morphological and Lexical Intensifiers in Spanish. Journal of Pragmatics 170: 125-38. [CrossRef]

Serradilla Castaño, Ana. 2018. De «asaz fermoso» a «mazo guapo»: La evolución de las fórmulas superlativas en español. In Actas del X Congreso Internacional de Historia de la Lengua Española: Zaragoza, 7-11 de septiembre de 2015. Zaragoza: Institución Fernando el Católico, pp. 913-29.

Shoeni, Anna, Katharina Roser, and Martin Röösli. 2015. Memory performance, wireless communication and exposure to radiofrequency electromagnetic fields: A prospective cohort study in adolescent. Environment International 85: 343-51. [CrossRef] [PubMed]

Sonnenhauser, Barbara, and Patrizia N. Aziz Hanna, eds. 2013. Vocative!: Addressing between System and Performance. Berlin: De Gruyter Mouton.

Stenström, Anna-Brita. 2005. He's well nice-Es mazo majo: London and Madrid teenage girls' use of intensifiers. In The Power of Words: Studies in Honour of Moira Linnarud. Edited by Solveig Granath, June Miliander and Elisabeth Wenno. Karlstad: Karlstad University, pp. 207-16.

Stenström, Anna-Brita. 2008. Algunos rasgos característicos del habla de contacto en el lenguaje de adolescentes en Madrid. Oralia 11: 207-26.

Tagliamonte, Sali. 2008. So different and pretty cool! Recycling intensifiers in Toronto, Canada. English Language and Linguistics 12: 361-94. [CrossRef]

Tagliamonte, Sali. 2016. Teen Talk: The Language of Adolescents. Cambridge: Cambridge University Press.

Trudgill, Peter. 2020. Sociolinguistic typology and the speed of linguistic change. Journal of Historical Sociolinguistics 6: 1-13. [CrossRef]

Urichuk, Matthew, and Verónica Loureiro-Rodríguez. 2019. Brocatives: Self-reported use of vocatives in Manitoba (Canada). In It's Not All about You-New Perspectives on Address Research. Edited by Bettina Kluge and María Irene Moyna. Amsterdam and Philadelphia: John Benjamins, pp. 355-72.

Zeldes, Amir. 2012. Productivity in Argument Selection. From Morphology to Syntax. Berlin: Mouton de Gruyter.

Zeschel, Arne. 2012. Incipient Productivity: A Construction-Based Approach to Linguistic Creativity. Berlin and New York: Mouton De Gruyter.

Zimmermann, Klaus. 2002. La variedad juvenil y la interacción verbal entre jóvenes. In El Lenguaje de los Jóvenes. Edited by Félix Rodríguez González. Barcelona: Ariel, pp. 137-64. 